\title{
Temperature-Induced Degradation of Thin-Film III-V Solar Cells for Space Applications
}

\author{
R. H. van Leest, P. Mulder, N. Gruginskie, S. C. W. van Laar, G. J. Bauhuis, H. Cheun, H. Lee, W. Yoon, \\ R. van der Heijden, E. Bongers, E. Vlieg and J. J. Schermer
}

\begin{abstract}
High efficiency, thin-film III-V solar cells offer excellent characteristics for implementation in flexible solar panels for space applications. In order to investigate the space compatibility of such cells. The temperature-induced degradation of both substrate-based cells with $\mathrm{Au}$ and $\mathrm{Au} / \mathrm{Cu}$ contacts and thin-film cells on $\mathrm{Au}$ and $\mathrm{Cu}$ carriers was studied by accelerated ageing testing (AAT) at $200^{\circ} \mathrm{C}$. With less than $3 \%$ decrease in efficiency after 37 days at $200^{\circ} \mathrm{C}$ (equivalent to 10 years at $100^{\circ} \mathrm{C}$ for $\mathrm{E}_{\mathrm{a}}$ $=0.70 \mathrm{eV}$ ) the substrate-based cells show excellent results. With a $10 \%$ decrease in efficiency after 37 days of AAT the thin-film cells on an Au carrier exhibit promising results, given the early stage of development of the thin-film cells. On the other hand severe degradation is observed for thin-film cells on a $\mathrm{Cu}$ carrier (decrease in efficiency $>60 \%$ after 37 days of AAT). At least two factors contribute to this severe degradation: thermally-induced stress and $\mathrm{Cu}$ diffusion.
\end{abstract}

\section{INTRODUCTION}

$\mathbf{N}$ OVEL III-V solar cell preparation approaches such as inverted metamorphic (IMM) growth [1]-[3], waferbonding [4] and mechanical stacking [5] require at least one growth substrate removal to create an operational device. Techniques such as epitaxial lift-off (ELO) [6]-[9] and controlled spalling [10], [11] allow for substrate removal without destruction of the expensive growth substrate, thus allowing for substrate re-use [12], [13]. The released active cell structures have the intrinsic potential to be turned into genuine thin-film devices if they are transferred to a thin and flexible carrier. Such thin-film III-V devices offer excellent characteristics for implementation in next generation space solar panels, as they allow for a significant weight reduction on panel level [14], while at the same time offering the highest possible solar cell efficiencies [3], [15], [16]. Space, however, also provides a harsh environment (vacuum, harsh UV, electron and proton radiation, temperature cycling) which adds additional design challenges. Unfortunately reports of space environmental testing of thin-film III-V solar cells are scarce [17]-[20] and a number of design challenges remain to be addressed. These include the need for thin-film interconnection techniques, suitable radiation and UV resistant flexible cover

R.H. van Leest, P. Mulder, N. Gruginskie, S.C.W. van Laar, G.J. Bauhuis, E. Vlieg and J.J. Schermer are with the Radboud University, Institute for Molecules and Materials, Heyendaalseweg 135, 6525 AJ Nijmegen, The Netherlands, e-mail: L.vanLeest@science.ru.nl.

H. Cheun, H. Lee and W. Yoon are with LG Electronics Materials \& Devices Advanced Research Institute, 16 Woomyeon-Dong, Seocho-Gu, Seoul 137-724, Korea.

R. van der Heijden and E. Bongers are with Airbus Defence and Space Netherlands B.V., Mendelweg 30, 2333 CS Leiden, The Netherlands. glasses [14], [21] and in particular a space compatible flexible carrier and support.

Both the ELO and controlled spalling techniques already implement metal foil carriers as flexible handling and thin-film support during substrate removal [22]-[26]. The ELO process currently used at Radboud University utilizes a $\mathrm{Cu}$ carrier for handling and support of the thin-film semiconductor structures, as $\mathrm{Cu}$ is relatively cheap, compatible with all (post-)ELO solar cell processing steps and can be easily applied by a number of chemical and physical deposition processes. However, $\mathrm{Cu}$ is also known to diffuse rapidly into many semiconductors [27] and to introduce mid band gap trap levels [28]. The harsh environment provided by space (particularly the elevated maximum temperature during temperature cycling) may induce $\mathrm{Cu}$ diffusion, having a potentially detrimental effect on the device performance. The main objective of this study is to investigate the temperature-induced degradation of thin-film solar cells on $\mathrm{Cu}$ carrier foils.

Unfortunately, standardized test procedures to address temperature-induced degradation of (bare) thin-film III-V solar cells have not yet been developed. Since $\mathrm{Cu}$ diffusion is exponentially temperature dependent $\left(\mathrm{D}=\mathrm{D}_{0} \exp \left(-\mathrm{E}_{\mathrm{a}} / \mathrm{kT}\right)\right)$ an accelerated life-time testing (ALT) procedure can be used to accelerate the degradation process. ALT assumes that exposure for a long period of time to a (relatively) low temperature equals a short exposure (few days) to a higher temperature. This can be described with the following equation [29]:

$$
\frac{\mathrm{t}_{\mathrm{op}}}{\mathrm{t}_{\mathrm{acc}}}=\exp \left[\frac{\mathrm{E}_{\mathrm{a}}}{\mathrm{k}}\left(\frac{1}{\mathrm{~T}_{\mathrm{op}}}-\frac{1}{\mathrm{~T}_{\mathrm{acc}}}\right)\right]
$$

in which $\mathrm{k}$ is the Boltzmann constant, $\mathrm{E}_{\mathrm{a}}$ the activation energy for the degradation process, $\mathrm{T}_{\mathrm{op}}$ the regular operation temperature, $T_{\text {acc }}$ the accelerated test temperature and $t_{\mathrm{op}}$ and $t_{\mathrm{acc}}$ the exposure times to the corresponding temperatures. Typically the actual operation conditions (illumination, bias voltage, vacuum) are simulated during such tests [30], [31]. In order to exclude additional (i.e. non temperature-induced) light- and/or electrically-induced degradation mechanisms these operating conditions were excluded in our test procedure. In order to distinguish this procedure from regular ALT we will refer to this adapted procedure as accelerated ageing testing (AAT).

The main difficulty with both ALT and AAT is that it requires a known activation energy. Unfortunately experimental determination is difficult and hence there are very few activation energies reported for solar cell degradation [29], [32], [33] and none of these concern $(\mathrm{Cu})$ diffusion. The European Cooperation for Space Standardization (ECSS) standard for 


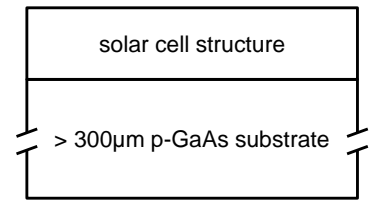

a) substrate-based structure

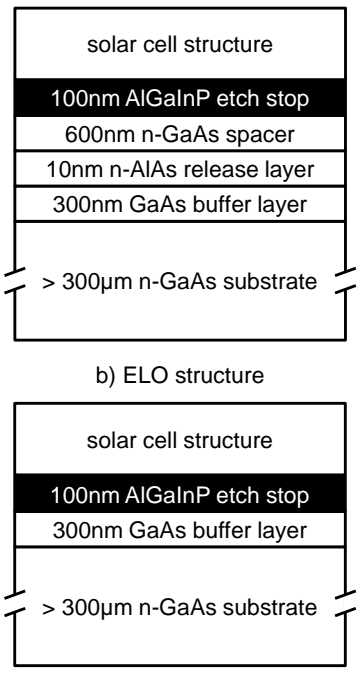

c) substrate etch structure
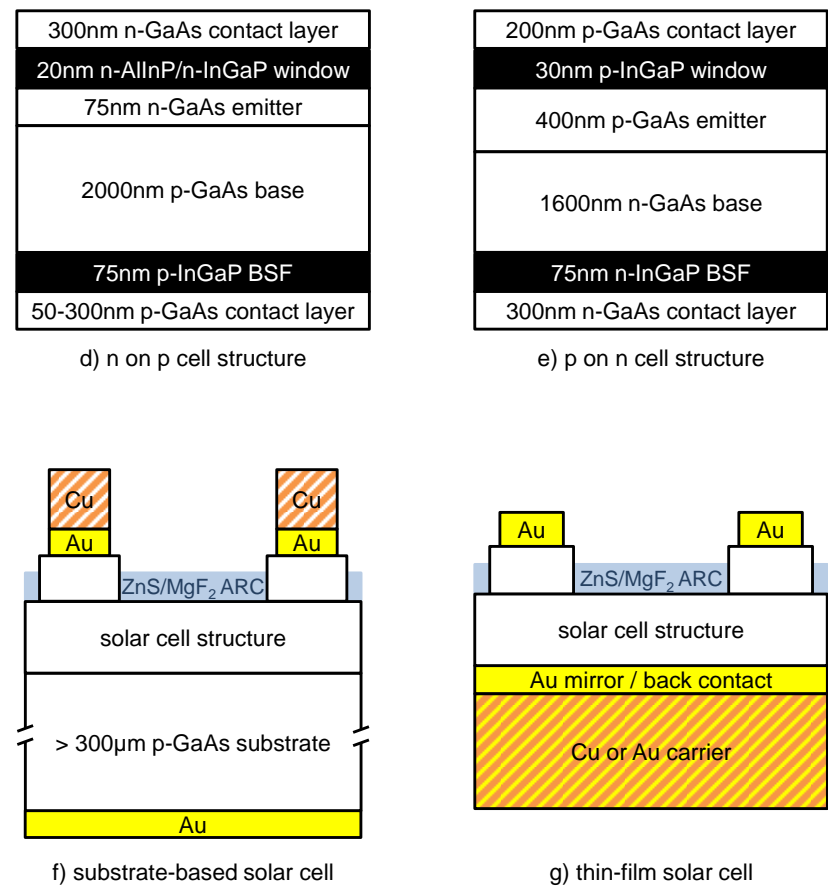

g) thin-film solar cell

Figure 1. Schematic representations of a) a substrate-based structure b) an ELO structure c) a substrate etch structure d) a n on p solar cell structure e) a $\mathrm{p}$ on $\mathrm{n}$ solar cell structure f) a substrate-based solar cell and g) a thin-film solar cell. The solar cell structures (d and e) were grown upright on top of the substrate-based (a), ELO (b) or substrate etch (c) structures unless specified otherwise. The substrate-based structures (a) were processed into substrate-based solar cells (f) and the ELO (b) and substrate etch (c) structures were processed into thin-film solar cells (g).

photovoltaic assemblies and components (ECSS-EST-20-08C [31]) advises to use an $\mathrm{E}_{\mathrm{a}}$ of $0.70 \mathrm{eV}$ in calculations for solar cell assemblies (solar cells with cover glass, interconnect and (if used) bypass diode), this appears to be a suitable initial estimate for the activation energy. For an accelerated test temperature of $200^{\circ} \mathrm{C}$ this $\mathrm{E}_{\mathrm{a}}$ of $0.70 \mathrm{eV}$ results in ALT/AAT times of 8.5, 37 and 55 days for simulation of a Geosynchronous orbit mission (GEO, 15 years, $\max 70^{\circ} \mathrm{C}$ ), a Low-Earth orbit mission (LEO, 10 years, $\max 100^{\circ} \mathrm{C}$ ) and an extreme scenario $\left(15\right.$ years, $\left.\max 100^{\circ} \mathrm{C}\right)$ respectively.

In previous studies [34], [35] a substrate-based model system utilizing a $45 \%$ coverage front contact grid was used to investigate the effects of $\mathrm{Cu}$ diffusion on GaAs solar cells. In these studies it was shown that at temperatures $<250^{\circ} \mathrm{C} \mathrm{Cu}$ diffusion has no significant effect on the $\mathrm{J}-\mathrm{V}$ characteristics of (substrate-based) solar cells. In this paper we report the first results of accelerated ageing testing (AAT) at $200^{\circ} \mathrm{C}$ of thin-film III-V solar cells on $\mathrm{Cu}$ and $\mathrm{Au}$ carriers and compare them with the AAT results of substrate-based solar cells with and without $\mathrm{Cu}$. Three different types of cells on a $\mathrm{Cu}$ carrier were compared: regular ELO n-type emitter on p-type base cells, ELO p-type emitter on n-type base cells and $n$ on $p$ cells obtained by substrate etching. These three different cell types were chosen as $\mathrm{Cu}$ diffusion may affect $\mathrm{n}$-type and $\mathrm{p}$ type material differently and $\mathrm{Cu}$ is at the n-type side in the substrate-based cells and on the p-type side in conventional $n$ on p ELO cells; and in order to exclude the potential effects of the ELO process (particularly the sample bending during lift-off) on the diffusion process, substrate etched cells were prepared in such a way that they remained planar during the entire production process.

\section{Materials And METHods}

\section{A. Solar cell processing}

The substrate-based, ELO and substrate etch solar cell structures as schematically depicted in figures $1 \mathrm{a}, 1 \mathrm{~b}$ and $1 \mathrm{c}$ were grown on 2" substrates in an Aixtron 200 MOCVD reactor at Radboud University or obtained from a third party supplier on 4" substrates. The epilayers for the cell structures were grown in upright order and $\mathrm{Zn}$ was used for p-type doping and Si for n-type doping, the $\mathrm{n}$-GaAs contact layers were Te-doped. Except for the ELO cells on an Au carrier which were grown inverted and with a Si-doped n-type contact layer. InGaP windows were used for the $\mathrm{p}$ on $\mathrm{n}$ cells and the cells on an Au carrier, while AlInP windows were used in the $\mathrm{n}$ on $\mathrm{p}$ cells on a $\mathrm{Cu}$ carrier and for the substrate-based cells. The thickness of the p-type contact layer of the $n$ on p cells was varied: $300 \mathrm{~nm}$ for the substrate-based cells and ELO cells on an Au carrier, $50 \mathrm{~nm}$ for the first series of ELO cells on a $\mathrm{Cu}$ carrier (labelled (1)) and $100 \mathrm{~nm}$ for the substrate etched cells and the second series of ELO cells on a Cu carrier (labelled (2)). 
First a flexible handle was applied to the thin-film solar cell structures after which they were removed from their growth substrates either by epitaxial lift-off [12] or by substrate etching with a 5:1 citric acid $\left(1 \mathrm{~kg}\right.$ in $\left.1 \mathrm{~kg} \mathrm{H}_{2} \mathrm{O}\right): \mathrm{H}_{2} \mathrm{O}_{2}$ (32\%) solution. After substrate removal the cell structures were transferred to $\mathrm{a} \sim 20 \mu \mathrm{m} \mathrm{Au} \mathrm{mirror/back} \mathrm{contact/carrier}$ or to $\mathrm{a} \sim 25 \mu \mathrm{m} \mathrm{Cu}$ carrier with a $100 \mathrm{~nm} \mathrm{Au} \mathrm{mirror/back}$ contact (the Au acts as a photon confining mirror [36]-[39]) and then mounted on a temporary glass carrier for further processing. Then a $45 \%$ coverage $200 \mathrm{~nm}$ thick Au front contact grid was applied by e-beam evaporation. For the substrate-based cells first $45 \%$ coverage metal front contacts (100 nm Au or $100 \mathrm{~nm} \mathrm{Au} \mathrm{/} 3 \mu \mathrm{m} \mathrm{Cu}$ ) and $100 \mathrm{~nm} \mathrm{Au} \mathrm{back}$ contacts were applied by e-beam evaporation. After application of the contacts $6 \mathrm{~mm} \times 6 \mathrm{~mm}$ solar cells were created by a MESA etch. A 1:2:10 $\mathrm{NH}_{4} \mathrm{OH}: \mathrm{H}_{2} \mathrm{O}_{2}: \mathrm{H}_{2} \mathrm{O}$ solution was used for the GaAs layers and a 1:100:200 $\mathrm{Br}_{2}: \mathrm{HBr}_{2} \mathrm{H}_{2} \mathrm{O}$ solution (thin-film cells) or $37 \% \mathrm{HCl}$ solution (substrate-based cells) was used for the AlInP and InGaP layers. For the thinfilm cells all semiconductor layers were removed, in such a way that the Au mirror / back contact became exposed after the MESA etch, for the substrate-based cells only the front contact, window, emitter and base layers were removed. Then the front contact layer between the metal grid fingers was removed with 2:1:10 $\mathrm{NH}_{4} \mathrm{OH}: \mathrm{H}_{2} \mathrm{O}_{2}: \mathrm{H}_{2} \mathrm{O}$ solution. Finally a $\mathrm{ZnS}(42.5 \mathrm{~nm}) / \mathrm{MgF}_{2}(88.0 \mathrm{~nm})$ anti-reflection coating was applied by e-beam evaporation. The thin-film samples were then removed from their temporary glass carrier and cut into smaller pieces typically including 3-6 cells with a scalpel.

\section{B. Characterization and accelerated life-time testing}

After cell preparation the solar cells were characterized by $\mathrm{J}-\mathrm{V}$ measurements with an ABET 2000 solar simulator and ReRa Tracer 3.0 measurement software and by EQE measurements with a ReRa SpeQuest system with ReRa Photor 3.1 measurement software. Sets of 3-6 cells were then exposed to stepwise accelerated ageing testing (AAT) in a vacuum oven at $200^{\circ} \mathrm{C}$ up to a total of 37 days (equivalent to 10 years at $100^{\circ} \mathrm{C}$ for an $\mathrm{E}_{\mathrm{a}}$ of $0.70 \mathrm{eV}$ ), for some of the cells the test was extended to 55 days (equivalent to 15 years at $100^{\circ} \mathrm{C}$ for $\mathrm{E}_{\mathrm{a}}=0.70 \mathrm{eV}$ ). After each AAT step the J-V and EQE of the cells were measured and for the short-circuit current density $\left(\mathrm{J}_{\mathrm{sc}}\right)$, the open-circuit voltage $\left(\mathrm{V}_{\mathrm{oc}}\right)$, the fill factor $(\mathrm{FF})$ and the efficiency $(\eta)$ remaining factors $(\mathrm{R})$ were calculated according to:

$$
\text { R-parameter }=\frac{\text { parameter value after AAT }}{\text { parameter value as processed }} .
$$

The $R$ values were then averaged over the set of cells.

Based on the results of the AAT, a number of cells were selected for transmission electron microscopy (TEM) analysis. These solar cells were covered with a thin Pt protection layer. A cross-section was made and then thinned using focused ion beam milling to allow for cross-sectional TEM analysis of the front contacts. TEM images were obtained with a FEI Titan G2 microscope.
Table I

AVERAGE BEGINNING OF LIFE (BOL) VALUES OF $\mathbf{J}_{\mathrm{SC}}, \mathrm{V}_{\mathrm{OC}}$, FF AND $\eta$ FOR THE DIFFERENT CELL TYPES.

\begin{tabular}{l|cccc} 
& $\begin{array}{c}\mathrm{J}_{\mathrm{sc}} \\
\left(\mathrm{mA} / \mathrm{cm}^{2}\right)\end{array}$ & $\begin{array}{c}\mathrm{V}_{\mathrm{oc}} \\
(\mathrm{mV})\end{array}$ & $\begin{array}{c}\mathrm{FF} \\
(\%)\end{array}$ & $\begin{array}{c}\eta \\
(\%)\end{array}$ \\
\hline Au Sub n on p & 15.6 & 1022.4 & 82.4 & 13.1 \\
$\mathrm{Cu}$ Sub n on p & 15.2 & 970.4 & 83.0 & 12.3 \\
$\mathrm{Au}$ ELO n on p & 15.6 & 1029.3 & 83.5 & 13.4 \\
$\mathrm{Cu}$ ELO n on p (1) & 16.4 & 1008.8 & 83.9 & 13.9 \\
$\mathrm{Cu}$ ELO n on p (2) & 16.2 & 1003.3 & 82.4 & 13.3 \\
$\mathrm{Cu}$ ELO p on n & 14.7 & 986.7 & 78.5 & 11.4 \\
$\mathrm{Cu}$ SubEtch n on p & 11.4 & 989.8 & 82.6 & 9.4
\end{tabular}

\section{RESUlTS AND DisCUSSION}

The average beginning of life (BOL) values for $\mathrm{J}_{\mathrm{sc}}, \mathrm{V}_{\mathrm{oc}}$, FF and $\eta$ of the different cell types are given in table I. The $\mathrm{V}_{\mathrm{oc}}$ values of $\sim 1.00 \mathrm{~V}$ and FFs of $82-83 \%$ are typical values for reasonable quality GaAs solar cells. The $\mathrm{J}_{\mathrm{sc}}$ values may at first glance appear to be rather low, but can be accounted for by the $45 \%$ coverage front grid which significantly limits the amount of light entering the cells. The somewhat poorer efficiencies of the Cu ELO $\mathrm{p}$ on $\mathrm{n}$ and $\mathrm{Cu}$ substrate etch $\mathrm{n}$ on $\mathrm{p}$ cells can be accounted for by the fact that device design and cell processing were not yet optimized for these types of samples.

In figure 2 the average $\mathrm{J}_{\mathrm{sc}}, \mathrm{V}_{\mathrm{oc}}, \mathrm{FF}$ and $\eta$ remaining factors of substrate-based and thin-film cells with and without $\mathrm{Cu}$ are plotted as a function of AAT time. Both the Au and $\mathrm{Cu}$ substrate-based cells show little degradation, indicated by the R- $\eta$ values which remain above 0.97 after 37 days at $200^{\circ} \mathrm{C}$. The other remaining factors indicate that this minor decrease in performance is mainly due to decreases in $\mathrm{V}_{\mathrm{oc}}$ and FF. $\mathrm{V}_{\mathrm{oc}}$ losses are typically caused by enhanced nonradiative recombination, while decreases in FF may be related to changes in $\mathrm{J}_{\mathrm{sc}}, \mathrm{V}_{\mathrm{oc}}$ and resistance. As these decreases occur for both $\mathrm{Au}$ and $\mathrm{Cu}$ contacts, they must be caused by general (i.e. non $\mathrm{Cu}$ specific) temperature-induced degradation mechanisms. These results clearly indicate that, under these conditions, the application of a thick $(3 \mu \mathrm{m}) \mathrm{Cu}$ layer in a III$\mathrm{V}$ solar cell does not affect device performance significantly and hence that $\mathrm{Cu}$ diffusion from the contact into the active solar cell should not be an issue for application of $\mathrm{Cu}$ in space solar panels.

For the thin-film cells on an Au carrier the decrease in efficiency upon AAT is almost $10 \%$ after 37 days at $200^{\circ} \mathrm{C}$, mainly caused by decreases in $\mathrm{V}_{\text {oc }}$ and FF. This slightly larger degradation compared to substrate-based cells is likely to be (at least partially) caused by non-optimized thin-film cell processing which is in an early stage of development compared to substrate-based processing. In contrast with the cells on an $\mathrm{Au}$ carrier, all cells on a $\mathrm{Cu}$ carrier show severe and rapid degradation as is indicated by the $\mathrm{R}-\eta$ values (see figure $2 \mathrm{~d}$ ) which are already below 0.85 after 4.25 days. Although there are differences between the different sample types, the general degradation trends are similar for all cells on a $\mathrm{Cu}$ carrier. Initially rapid decreases in all parameters can be observed. Whereas the initial rapid degradation of the $n$ on $p$ cells starts 

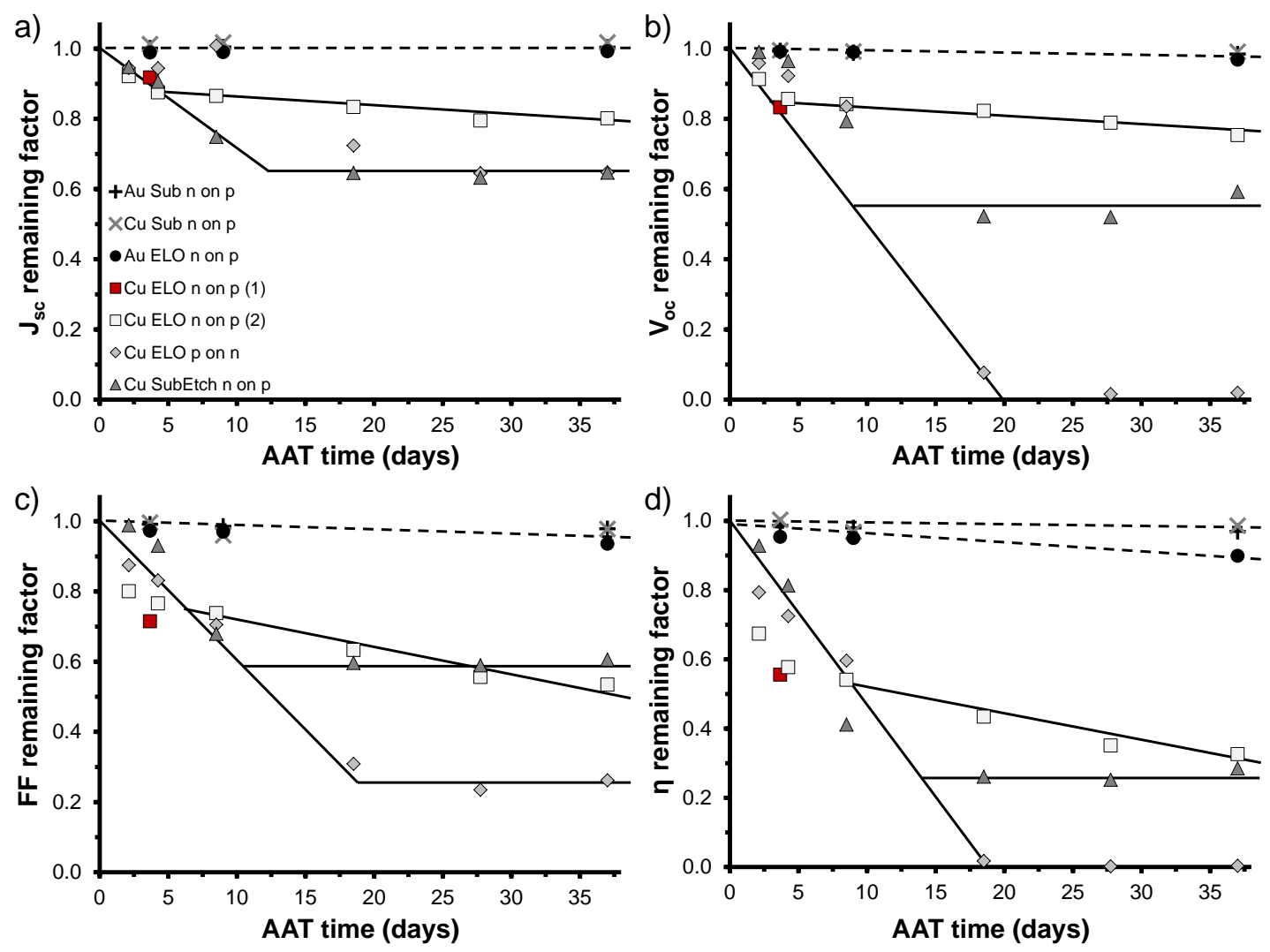

Figure 2. Average a) $\mathrm{J}_{\mathrm{sc}}$ b) $\mathrm{V}_{\mathrm{oc}}$ c) fill factor (FF) and d) efficiency $(\eta$ ) remaining factors plotted versus AAT time for $\mathrm{n}$ on $\mathrm{p}$ substrate-based cells with 100 $\mathrm{nm} \mathrm{Au}$ front contacts (black + signs), $\mathrm{n}$ on p substrate-based cells with $100 \mathrm{~nm} \mathrm{Au} \mathrm{/} 3 \mu \mathrm{m}$ Cu front contacts (grey x signs), $\mathrm{n}$ on $\mathrm{p}$ ELO cells on an Au carrier (black circles), $\mathrm{n}$ on $\mathrm{p}$ ELO cells on a $\mathrm{Cu}$ carrier (red and light grey squares), $\mathrm{p}$ on $\mathrm{n}$ ELO cells on a Cu carrier (grey diamonds) and $\mathrm{n}$ on $\mathrm{p}$ substrate etched cells on a $\mathrm{Cu}$ carrier (grey triangles). The dashed lines indicate the general degradation trends for substrate-based cells and thin-film cells on an Au carrier, the solid lines indicate the trends for thin-film cells on a $\mathrm{Cu}$ carrier.

to level of after 5-10 days, resulting in R- $\eta$ values of about 0.3 after 37 days of AAT, the rapid degradation of the $\mathrm{p}$ on $\mathrm{n}$ cells continues (in particular for $\mathrm{V}_{\mathrm{oc}}$ and $\mathrm{FF}$ ), resulting in nonoperational cells after 18 days. This hints that n-type GaAs is more prone to $\mathrm{Cu}$ diffusion, if $\mathrm{Cu}$ diffusion is a process contributing to device degradation. However the fact that the substrate-based cells also have the $\mathrm{Cu}$ at the n-type side and hardly show any degradation indicates that there is at least one other degradation mechanism that has a major impact on the degradation process. The fact that both the substrate-etched and ELO $\mathrm{n}$ on $\mathrm{p}$ thin-film cells show a very similar degradation trend indicates that the manipulation of the thin-film during the ELO process does not inflict damage that is detrimental to the solar cell device operation.

The significant decrease in $\mathrm{J}_{\mathrm{sc}}$ observed for the thin-film cells on $\mathrm{Cu}$ carriers is in sharp contrast with the small changes (typically 1-2\%) observed for cells on an Au carrier and substrate-based cells with and without $\mathrm{Cu}$ (both in this study and in previous work [34], [35], [40]). This indicates that the degradation process causing the decrease in $\mathrm{J}_{\mathrm{sc}}$ is specific for thin-film cells on a $\mathrm{Cu}$ carrier and therefore of interest for further investigation. The decrease in $\mathrm{J}_{\mathrm{sc}}$ is (at least partially) caused by a reflectivity loss of the Au mirror that is applied to reflect transmitted and recycled photons back into the solar cell [36], [37], [39]. Figures $3 \mathrm{a}$ and $3 \mathrm{~b}$ show an as processed

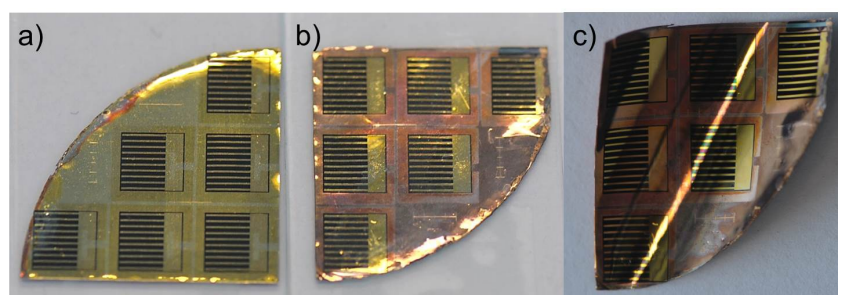

Figure 3. ELO $\mathrm{n}$ on $\mathrm{p}$ thin-film solar cells on a $\mathrm{Cu}$ carrier with $100 \mathrm{~nm} \mathrm{Au}$ mirror a) as processed and b) and c) after 37 days AAT at $200^{\circ} \mathrm{C}$. For images a) and b) the samples were placed behind a glass plate to keep them flat. Without this glass plate the samples show significant curvature, in particular after AAT as is shown in image c).

ELO thin-film sample and an ELO thin-film sample after exposure to AAT. Around the cells the as processed sample shows the yellowish colour of the gold mirror/back contact, while the sample exposed to AAT has a reddish $\mathrm{Cu}$ colour, indicating that $\mathrm{Cu}$ from the carrier has diffused through the Au mirror/back contact during AAT. The same colour change is observed for all samples on a $\mathrm{Cu}$ carrier.

TEM images show that the rear interface of thin-film cells on $\mathrm{Au}$ and $\mathrm{Cu}$ carrier are remarkably different upon exposure to AAT. After 55 days at $200^{\circ} \mathrm{C}$ the cell on an Au carrier shows a smooth $\mathrm{Au} / \mathrm{GaAs}$ interface at the back (see figure 


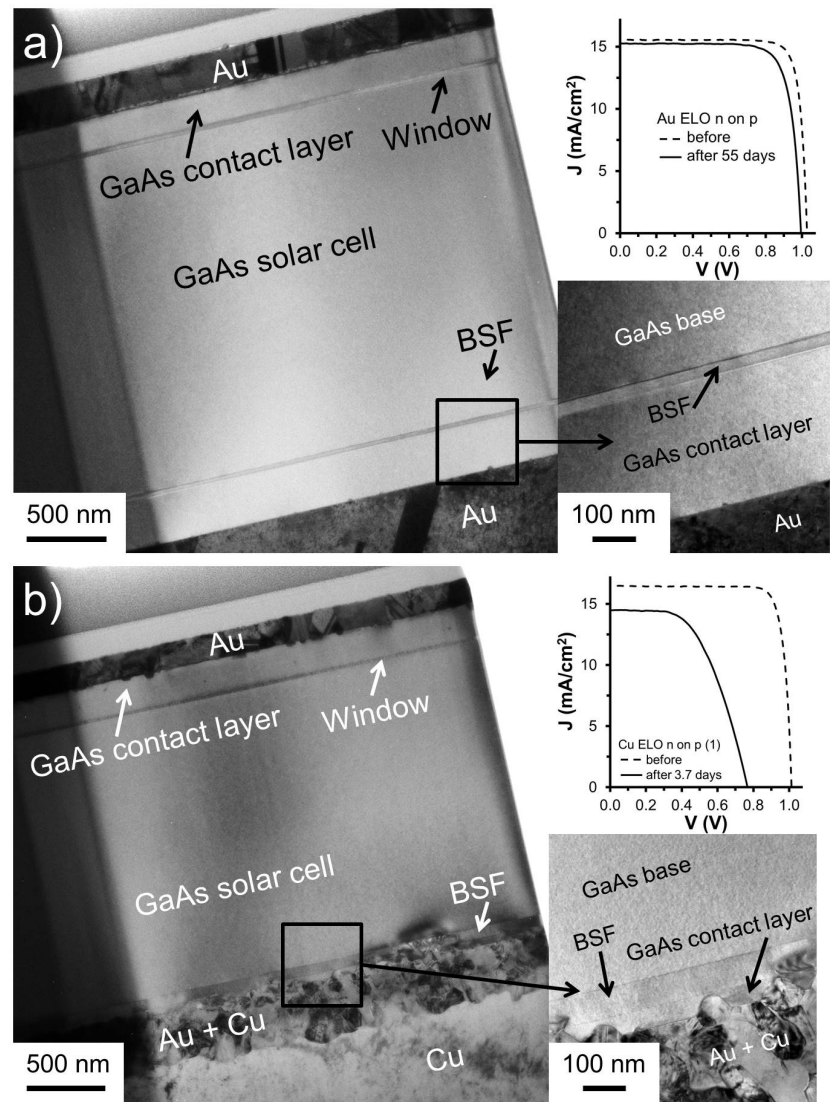

Figure 4. TEM images of a) a thin-film ELO cell on an Au carrier after 55 days at $200^{\circ} \mathrm{C}$ and b) a thin-film ELO cell on a $\mathrm{Cu}$ carrier after 3.7 days at $200^{\circ} \mathrm{C}$. The inserts on the right show the $\mathrm{J}-\mathrm{V}$ curves before (dashed curve) and after (solid curve) AAT and an enlargement of the back of the solar cell.

4a), whereas the cell on a $\mathrm{Cu}$ carrier shows an intermixed $\mathrm{Au} / \mathrm{Cu}$ layer and a GaAs contact layer that appears to have been almost fully consumed by the $\mathrm{Au} / \mathrm{Cu}$ matrix already after 3.7 days at $200^{\circ} \mathrm{C}$ (see figure $4 \mathrm{~b}$ ). This undulation of the metal/GaAs interface and intermixing of the $\mathrm{Au}$ and $\mathrm{Cu}$ is similar to the undulation and intermixing previously observed for substrate-based cells after $1320 \mathrm{~h}$ (55 days) at $200^{\circ} \mathrm{C}$ (see figure $6 \mathrm{~b}$ in reference [35]). The intermixing of the $\mathrm{Au}$ and $\mathrm{Cu}$ is in agreement with the observed colour change of the carrier foil (see figure 3). The intermixing and particularly the undulation of the $\mathrm{Au} / \mathrm{GaAs}$ interface indicates severe degradation of the Au mirror.

The reflectivity loss of the mirror can also be deduced from the EQE data of the cells. In figure 5a the EQE of an $n$ on $p$ thin-film ELO cell on an Au carrier is plotted before AAT and after 9 days at $200^{\circ} \mathrm{C}$ and in figure $5 \mathrm{~b}$ the $\mathrm{EQE}$ of an $\mathrm{n}$ on $\mathrm{p}$ ELO thin-film cell on a $\mathrm{Cu}$ carrier is plotted before AAT, after 8.5 days and after 37 days at $200^{\circ} \mathrm{C}$. After AAT the interference fringes in the 700-900 nm range caused by the reflection of the mirror [41] have disappeared for the cell on a $\mathrm{Cu}$ carrier, but remain visible for the cell on an $\mathrm{Au}$ carrier. This clearly shows that in the cells on a $\mathrm{Cu}$ carrier the mirror properties of the Au are severely degraded upon AAT. Additionally the EQE data show that the loss in $\mathrm{J}_{\mathrm{sc}}$ for the cells on a $\mathrm{Cu}$ carrier is mainly caused by a reduced collection
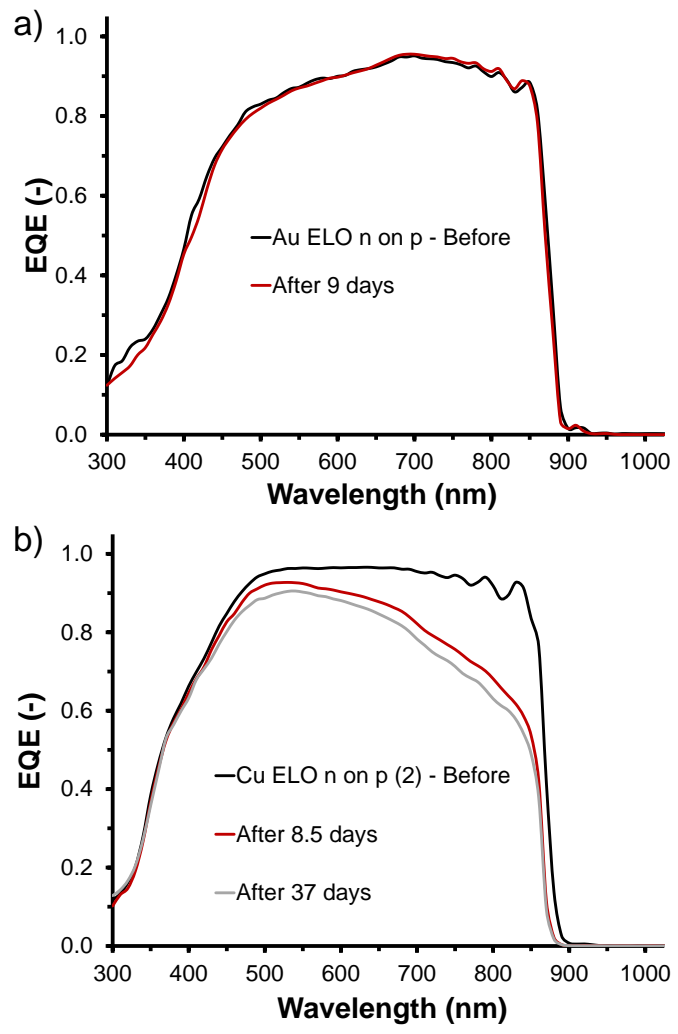

Figure 5. External quantum efficiency (EQE) of a) a thin-film ELO n on $p$ solar cell on a Au carrier before AAT (black curve) and after 9 (red curve) days of AAT at $200^{\circ} \mathrm{C}$ and b) a thin-film ELO $\mathrm{n}$ on p solar cell on a $\mathrm{Cu}$ carrier with 100nm Au mirror before AAT (black curve) and after 8.5 (red curve) and 37 (grey curve) days of AAT at $200^{\circ} \mathrm{C}$.

efficiency of carriers created by long wavelength $(600-900 \mathrm{~nm})$ photons, which are mostly absorbed at the back of the cell. The fact that no reduction in collection efficiency is observed for the cell on an Au carrier suggests that the decrease for the cells on a $\mathrm{Cu}$ carrier is $\mathrm{Cu}$ related. Two mechanisms contribute to the loss in collection efficiency: reduced reflection of photons by the mirror and diffusion of $\mathrm{Cu}$ into the active cell, creating trap levels that reduce the carrier collection efficiency.

Next we discuss $\mathrm{V}_{\mathrm{oc}}$. The decrease in $\mathrm{V}_{\mathrm{oc}}$ of the thinfilm cells on $\mathrm{Cu}$ carrier is far more severe than the decreases observed for substrate-based cells and thin-film cells on an $\mathrm{Au}$ carrier. As decreases in $\mathrm{V}_{\mathrm{oc}}$ are typically related to increases in the (non-radiative) recombination current and $\mathrm{Cu}$ is known to introduce trap levels in the band gap [28] which act as recombination centres, the decreases in $\mathrm{V}_{\mathrm{oc}}$ are most likely related to the introduction of $\mathrm{Cu}$ trap levels as a result of $\mathrm{Cu}$ diffusion. The colour change of the metal foil as depicted in figure 3, the intermixing of $\mathrm{Au}$ and $\mathrm{Cu}$ and the undulation of the $\mathrm{Au} / \mathrm{GaAs}$ interface observed in the TEM images (figure $4 \mathrm{~b}$ ) and the reduced collection efficiency in the long wavelength range of the $\mathrm{EQE}$ (figure 5) all indicate that $\mathrm{Cu}$ diffusion indeed takes place. Direct quantitative measurement of $\mathrm{Cu}$ diffusion by for example SIMS is difficult as the concentration of $\mathrm{Cu}$ causing an electrical effect is most likely significantly below the detection limit of such methods. A problem that was already discussed by Istratov et al. for $\mathrm{Cu}$ diffusion in 
silicon [42]. However, as the substrate-based $\mathrm{Cu}$ cells do not show signs of $\mathrm{Cu}$ diffusion there must be a thin-film related process that induces/enhances the diffusion process. The image in figure $3 \mathrm{c}$ provides a possible explanation for the enhanced $\mathrm{Cu}$ diffusion in thin-film cells, as it shows that the carrier tends to curl upon exposure to AAT. This curling of the sample can be explained by the difference in thermal expansion coefficient between the $\mathrm{Cu}\left(16.5^{*} 10^{-6} \mathrm{~K}^{-1}\right)$ and $\mathrm{Au}\left(14.2^{*} 10^{-6} \mathrm{~K}^{-1}\right)$ on the one hand and GaAs $\left(5.4^{*} 10^{-6} \mathrm{~K}^{-1}\right)$ on the other. Upon exposure to AAT the metal expands more rapidly, thereby creating stress in the solar cell material. Such stress is likely to induce (micro-)cracks and other defects which are known to enhance diffusion [43], [44].

\section{CONCLUSIONS \& OUTLOOK}

In order to investigate the space compatibility of thin-film III-V solar cells, the temperature-induced degradation of thinfilm cells on $\mathrm{Cu}$ and $\mathrm{Au}$ carriers and substrate-based cells with $\mathrm{Au}$ and $\mathrm{Au} / \mathrm{Cu}$ front contacts was studied by accelerated ageing testing. The substrate-based cells show little degradation with a decrease in efficiency of $3 \%$ or less for both $\mathrm{Au}$ and $\mathrm{Au} / \mathrm{Cu}$ contacts (after 37 days, equivalent to 10 years at $100^{\circ} \mathrm{C}$ for an $E_{a}$ of $0.70 \mathrm{eV}$ ), which indicates that application of $\mathrm{Cu}$ in itself is not a threat to the long term device performance. The slight efficiency loss of $\sim 10 \%$ of the cells on an Au carrier after 37 days at $200^{\circ} \mathrm{C}$, indicates that there is a definite potential for the thin-film III-V cells in space modules. The severe degradation observed for the cells on $\mathrm{Cu}$ carriers (efficiency losses typically $>60 \%$ after 37 days at $200^{\circ} \mathrm{C}$ ) shows that the carrier material significantly influences the device stability. The fact that both ELO and substrate-etched thin-film cells on a $\mathrm{Cu}$ carrier show severe degradation indicates that the ELO process itself does not affect the device performance. At least two factors contribute to the decrease in solar cell performance: thermally induced stress and $\mathrm{Cu}$ diffusion. These two factors may influence each other as diffusion processes are likely to be enhanced by damage (such as cracks and defects) induced by thermal stress.

In order to improve long term stability of thin-film solar cells a better understanding of the effect(s) of thermally induced stress on the solar cell / carrier combination is required. As the actual maximum temperature reached during solar cell operation in space is significantly lower (typically max $\pm 100^{\circ} \mathrm{C}$, possibly somewhat higher in extreme circumstances) than the AAT temperature applied in this study $\left(200^{\circ} \mathrm{C}\right)$ the critical levels of stress induced by the AAT may not be reached during an actual space mission. Lowering the AAT temperature to a value well below $200^{\circ} \mathrm{C}$ may significantly reduce the thermally induced stress. Additionally, mounting the thin-film cells on a space compatible flexible mechanical support might help reducing the stress effects in the thin-film cells (i.e. preventing the thin-film cells from bending upon exposure to thermal stress). Furthermore, a solution for the intermixing of the $\mathrm{Au}$ mirror and $\mathrm{Cu}$ carrier and diffusion of $\mathrm{Cu}$ into the device has to be found. This could be achieved either by implementation of a barrier that prevents intermixing of the $\mathrm{Au}$ mirror/back contact and the $\mathrm{Cu}$ carrier or by replacement of the $\mathrm{Cu}$ carrier with a different (metal) carrier.

\section{ACKNOWLEDGEMENTS}

The authors would like to thank Wil Corbeek for the technical support. This project was financially supported by the Netherlands Space Office (NSO) under projectnumber PEP12010, by the European Union's Horizon 2020 research and innovation programme under grant agreement number 687253 and by the Brazilian National Council for Scientific and Technological Development under grant number 233259/2014-7.

\section{REFERENCES}

[1] J. F. Geisz, S. Kurtz, M. W. Wanlass, J. S. Ward, A. Duda, D. J. Friedman, J. M. Olson, W. E. McMahon, T. E. Moriarty, and J. T. Kiehl, "High-efficiency GaInP/GaAs/InGaAs triple-junction solar cells grown inverted with a metamorphic bottom junction," Applied Physics Letters, vol. 91, p. 023502, 2007.

[2] M. Stan, D. A. Aiken, B. Cho, A. Cornfeld, V. Ley, P. Patel, P. Sharps, and T. Varghese, "High-efficiency quadruple junction solar cells using OMVPE with inverted metamorphic device structures," Journal of Crystal Growth, vol. 312, pp. 1370-1374, 2010.

[3] R. M. France, J. F. Geisz, I. García, M. A. Steiner, W. E. McMahon, D. J. Friedman, T. E. Moriarty, C. Osterwald, J. S. Ward, A. Duda, M. Young, and W. Olavarria, "Quadruple-Junction Inverted Metamorphic Concentrator Devices," IEEE Journal of Photovoltaics, vol. 5, pp. 432437, 2015

[4] F. Dimroth, T. N. D. Tibbits, M. Niemeyer, P. F., P. Beutel, C. Karcher, E. Oliva, G. Siefer, D. Lackner, P. Fuß-Kailuweit, A. W. Bett, R. Krause, C. Drazek, E. Guiot, J. Wasselin, A. Tauzin, and T. Signamarcheix, "Four-Junction Wafer-Bonded Concentrator Solar Cells," IEEE Journal of Photovoltaics, vol. 6, pp. 343-349, 2016.

[5] M. A. Steiner, J. F. Geisz, J. S. Ward, I. García, D. J. Friedman, R. R. King, P. T. Chiu, R. M. France, A. Duda, W. J. Olavarria, M. Young, and S. R. Kurtz, "Optically Enhanced Photon Recycling in Mechanically Stacked Multijunction Solar Cells," IEEE Journal of Photovoltaics, vol. 6, pp. 358-365, 2016.

[6] E. Yablonovitch, T. Gmitter, J. P. Harbison, and R. Bnat, "Extreme selectivity in the lift-off of epitaxial GaAs films," Applied Physics Letters, vol. 51, pp. 2222-2224, 1987.

[7] A. van Geelen, P. R. Hageman, G. J. Bauhuis, P. C. van Rijsingen, P. Schmidt, and L. Giling, "Epitaxial lift-off GaAs solar cell from a reusable GaAs substrate," Materials Science and Engineering, vol. B45, pp. 162-171, 1997.

[8] J. van Deelen, G. J. Bauhuis, J. J. Schermer, P. Mulder, E. J. Haverkamp, and P. K. Larsen, "On the development of high-efficiency thin-film GaAs and GaInP 2 cells," Journal of Crystal Growth, vol. 298, pp. 772-776, 2007.

[9] R. Tatavarti, G. Hillier, A. Dzankovic, G. Martin, F. Tuminiello, R. Navaratnajarah, G. Du, D. P. Vu, and N. Pan, "Lightweight, low cost GaAs solar cells on 4" epitaxial lift-off (ELO) wafers," in 33rd IEEE Photovoltaics Specialists Conference, pp. 1-4, 2008.

[10] S. W. Bedell, D. Sharjerdi, B. Hekmatshoar, K. Fogel, P. A. Lauro, J. A. Ott, N. Sosa, and D. Sadana, "Kerf-Less Removal of Si, Ge, and III-V Layers by Controlled Spalling to Enable Low-Cost PV Technologies," IEEE Journal of Photovoltaics, vol. 2, pp. 141-147, 2012.

[11] D. Shahrjerdi, S. W. Bedell, C. Ebert, C. Bayram, B. Hekmatshoar, K. Fogel, P. Lauro, M. Gaynes, T. Gokmen, J. A. Ott, and D. K. Sadana, "High-efficiency thin-film InGaP/InGaAs/Ge tandem solar cells enabled by controlled spalling technology," Applied Physics Letters, vol. 100, p. 053901, 2012.

[12] G. J. Bauhuis, P. Mulder, E. J. Haverkamp, J. J. Schermer, E. Bongers, W. Köstler, and G. Strobl, "Wafer reuse for repeated growth of IIIV solar cells," Progress in Photovoltaics: Research and Applications, vol. 18, pp. 155-159, 2010.

[13] J. Adams, V. Elarde, A. Hains, C. Stender, F. Tuminello, C. Youtsey, A. Wibowo, and M. Osowski, "Demonstration of Multiple Substrate Reuses for Inverted Metamorphic Solar Cells,' IEEE Journal of Photovoltaics, vol. 3, pp. 899-903, 2013.

[14] J. Feenstra, R. H. van Leest, N. J. Smeenk, P. Mulder, G. Oomen, E. Vlieg, and J. J. Schermer, "Flexible shielding layers for solar cells in space applications," Journal of Applied Polymer Science, vol. 133, p. $43661,2016$. 
[15] I. Garcia, R. M. France, J. F. Geisz, W. E. McMahon, M. A. Steiner S. Johnston, and D. J. Friedman, "Metamorphic III-V Solar Cells: Recent Progress and Potential," IEEE Journal of Photovoltaics, vol. 6, pp. 366$373,2016$.

[16] R. France, J. Geisz, I. García, M. Steiner, W. McMahon, D. Friedman, T. Moriarty, C. Osterwald, J. Ward, A. Duda, M. Young, and W. Olavarria, "Design Flexibility of Ultrahigh Efficiency Four-Junction Inverted Metamorphic Solar Cells," IEEE Journal of Photovoltaics, vol. 6, pp. 578-583, 2016.

[17] J. J. Schermer, P. Mulder, G. J. Bauhuis, P. K. Larsen, G. Oomen, and E. Bongers, "Thin-film GaAs Epitaxial Lift-off Solar Cells for Space Applications," Progress in Photovoltaics: Research and Applications, vol. 13, pp. 587-596, 2005.

[18] C. Morioka, K. Shimazaki, S. Kawakita, M. Imaizumi, H. Yamaguchi, T. Takamoto, S. Sato, T. Ohshima, Y. Nakamura, K. Hirako, and M. Takahashi, "First flight demonstration of film-laminated InGaP/GaAs and Cigs thin-film solar cells by JAXA's small satellite in LEO," Progress in Photovoltaics: Research and Applications, vol. 19, pp. 825833, 2011.

[19] P. Patel, D. Aiken, A. Boca, B. Cho, D. Chumney, M. Clevenger, A. Cornfeld, N. Fatemi, Y. Lin, J. McCarty, F. Newman, P. Sharps, J. Spann, M. Stan, J. Steinfeldt, C. Strautin, and T. Varghese, "Experimental Results From Performance Improvement and Radiation Hardening of Inverted Metamorphic Multijuction Solar Cells," IEEE Journal of Photovoltaics, vol. 2, pp. 377-381, 2012.

[20] M. A. Steiner, M. P. Lumb, R. Hoheisel, J. F. Geisz, R. M. France, D. Scheiman, R. J. Walters, and P. P. Jenkins, "Radiation effects on luminescent coupling in III-V solar cells," in Proceedings of the 42nd IEEE Photovoltaic Specialists Conference, 2015.

[21] N. J. Smeenk, C. Mooney, J. Feenstra, P. Mulder, T. Rohr, C. O. A. Semprimoschnig, E. Vlieg, and J. J. Schermer, "Space environmental testing of flexible coverglass alternatives based on siloxanes," Polymer Degradation and Stability, vol. 98, pp. 2503-2511, 2013.

[22] C. Youtsey, J. Adams, R. Chan, V. Elarde, G. Hillier, M. Osowski, D. McCallum, H. Miyamoto, N. Pan, C. Stender, R. Tatavarti, F. Tuminello, and A. Wibowo, "Epitaxial Lift-Off of Large-Area GaAs ThinFilm Multi-Junction Solar Cells," in CS Mantech Conference, pp. 1-4, 2012.

[23] N. Pan, "Epitaxial Lift-Off of Large-Area GaAs Multi-Junction Solar Cells for High Efficiency Clean and Portable Energy Power Generation," in Proceedings of the 11th IEEE International Conference on Semiconductor Electronics, 2014.

[24] C. L. Stender, C. Youtsey, F. Tuminello, M. Osowski, J. Adams, V. Elarde, H. Miyamoto, A. Wibowo, G. Hillier, R. Tatavarti, and N. Pan, "Applications for Epitaxial Lift-Off of III-V Materials," in Lester Eastman Conference on High Performance Devices, 2014.

[25] S. W. Bedell, K. Fogel, P. Lauro, D. Shahrjerdi, J. A. Ott, and D. Sadana "Layer transfer by controlled spalling," Journal of Physics D: Applied Physics, vol. 46, p. 152002, 2013.

[26] D. Shahrjerdi, S. W. Bedell, C. Bayram, C. C. Lubguban, K. Fogel, P. Lauro, J. A. Ott, M. Hopstaken, M. Gayness, and D. Sadana, "Ultralight High-Efficiency Flexible InGaP/(In)GaAs Tandem Solar Cells on Plastic," Advanced Energy Materials, vol. 3, pp. 566-571, 2013.

[27] R. N. Hall and J. H. Racette, "Diffusion and Solubility of Copper in Extrinsic and Intrinsic Germanium, Silicon and Gallium Arsenide," Journal of Applied Physics, vol. 35, pp. 379-397, 1964.

[28] S. M. Sze and J. C. Irvin, "Resistivity, Mobility and Impurity Levels in $\mathrm{GaAs}, \mathrm{Ge}$, and $\mathrm{Si}$ at $300^{\circ} \mathrm{K}$," Solid-State Electronics, vol. 11, pp. 599$602,1968$.

[29] N. Núñez, J. R. González, M. Vázquez, C. Algora, and P. Espinet, "Evaluation of the reliability of high concentrator GaAs solar cells by means of temperature accelerated aging tests," Progress in Photovoltaics: Research and Applications, vol. 21, pp. 1104-1113, 2013.

[30] N. Núñez, M. Vazquez, V. Orlando, P. Espinet-González, and C. Algora, "Semi-quantitative temperature accelerated life test (ALT) for the reliability qualification of concentrator solar cells and cell on carriers," Progress in Photovoltaics: Research and Applications, vol. 23, pp. 18571866, 2015.

[31] ESA-ESTEC Requirements \& Standards Division, "ECSS-E-ST-20-08C, Space Engineering: Photovoltaic assemblies and components," 2012.

[32] M. Vázquez, C. Algora, I. Rey-Stolle, and J. R. González, "III-V Concentrator Solar Cell Reliability Prediction Based on Quantitative LED Reliability Data," Progress in Photovoltaics: Research and Applications, vol. 15, pp. 477-491, 2007.

[33] J. R. González, M. Vázquez, N. Núñez, C. Algora, I. Rey-Stolle, and B. Galiana, "Reliability analysis of temperature step-stress tests on III-
V high concentrator solar cells," Microelectronics Reliability, vol. 49, pp. 673-680, 2009.

[34] R. H. van Leest, G. J. Bauhuis, P. Mulder, R. van der Heijden, E. Bongers, E. Vlieg, and J. J. Schermer, "Effects of Copper Diffusion in Gallium Arsenide Solar Cells for Space Applications," Solar Energy Materials \& Solar Cells, vol. 140, pp. 45-53, 2015.

[35] R. H. van Leest, K. de Kleijne, G. J. Bauhuis, P. Mulder, H. Cheun, H. Lee, W. Yoon, R. van der Heijden, E. Bongers, E. Vlieg, and J. J. Schermer, "Degradation mechanism(s) of GaAs solar cells with $\mathrm{Cu}$ contacts," Physical Chemistry Chemical Physics, vol. 18, pp. 1023210240, 2016.

[36] G. J. Bauhuis, J. J. Schermer, P. Mulder, M. M. A. J. Voncken, and P. K. Larsen, "Thin film GaAs solar cells with increased quantum efficiency tue to light reflection," Solar Energy Materials \& Solar Cells, vol. 83, pp. 81-90, 2004.

[37] J. J. Schermer, G. J. Bauhuis, P. Mulder, E. J. Haverkamp, J. van Deelen, A. T. J. van Niftrik, and P. K. Larsen, "Photon confinement in highefficiency, thin-film III-V solar cells obtained by epitaxial lift-off," Thin Solid Films, vol. 511-512, pp. 645-653, 2006.

[38] O. D. Miller, E. Yablonovitch, and S. R. Kurtz, "Strong Internal and External Luminescence as Solar Cells Approach the Shockley-Queisser Limit," IEEE Journal of Photovoltaics, vol. 2, pp. 303-311, 2012.

[39] M. A. Steiner, J. F. Geisz, I. García, D. J. Friedman, A. Duda, and S. R. Kurtz, "Optical enhancement of the open-circuit voltage in high quality GaAs solar cells," Journal of Applied Physics, vol. 113, p. 123109, 2013.

[40] R. H. van Leest, K. de Kleijne, G. J. Bauhuis, P. Mulder, R. van der Heijden, E. Bongers, E. Vlieg, and J. J. Schermer, "Copper diffusion in GaAs solar cells for space applications," in Proceedings of the 31st European Photovoltaic Solar Energy Conference and Exhibition, pp. 1422-1425, 2015.

[41] G. J. Bauhuis, P. Mulder, E. J. Haverkamp, J. C. C. M. Huijben, and J. J. Schermer, " $26.1 \%$ thin-film GaAs solar cell using epitaxial lift-off," Solar Energy Materials \& Solar Cells, vol. 93, pp. 1488-1491, 2009.

[42] A. A. Istratov, C. Flink, and E. R. Weber, "Impact of the Unique Physical Properties of Copper in Silicon on Characterization of Copper Diffusion Barriers," Physica Status Solidi B, vol. 222, pp. 261-277, 2000.

[43] F. Hasegawa, "Different diffusion behavior of copper in epitaxial and in bulk GaAs," Journal of Applied Physics, vol. 45, pp. 1944-1947, 1974.

[44] M.-A. Nicolet, "Diffusion barriers in thin films," Thin Solid Films, vol. 52, pp. 415-443, 1978. 